\title{
TINDAK TUTUR ILOKUSI DALAM NOVEL SEPASANG BOLA MATA KARYA MAYSHIZA WIDYA
}

\author{
Nelly Khoiriah Lubis dan Suyatno \\ Program Studi Sastra Indonesia, Universitas Pamulang \\ dosen00776@unpam.ac.id
}

\begin{abstract}
Abstrak
Penelitian ini bertujuan untuk mendeskripiskan bentuk tindak tutur ilokusi pada novel Sepasang Bola Mata karya Mayshiza Widya. Penelitian ini menggunakan metode penelitian deskriptif kualitatif dengan pisau analisis kajian pragmatik. Hasil penelitian menunjukkan bahwa jenis tindak tutur ilokusi pada novel Sepasang Bola Mata yaitu tindak tutur asertif ditemukan 12 data, tindak tutur ekspresif ditemukan 13 data, tindak tutur direktif ditemukan 6 data, tindak tutur komisif ditemukan 5 data, dan tindak tutur deklaratif ditemukan 4 data. Adapun bentuk tindak tutur ilokusi ditemukan hanya dua, yaitu: tindak tutur langsung ditemukan 10 data, dan bentuk tindak tutur tidak langsung ditemukan 8 data. Tindak tutur langsung yang banyak ditemukan karena dalam novel Sepasang Bola Mata karya Mayshiza Widya tuturan antartokoh yang sering muncul adalah tuturan secara langsung dari pada tuturan secara tidak langsung.
\end{abstract}

Kata Kunci: Tindak Tutur Ilokusi, Novel, dan Pragmatik

\section{Pendahuluan}

Penelitian ini meneliti karya sasatra berupa novel, yaitu novel yang berjudul "Sepasang Bola Mata" karya Mayshiza Widya dengan kajian pragmatik. Penelitian ini berupaya untuk menemukan tindak tutur dengan cara mengamati percakapan atau menganalisis di dalam novel Sepasang Bola Mata.

Novel Sepasang Bola Mata karya Mayshiza Widaya menceritakan tentang seorang gadis buta yaitu Ara yang tidak mempunyai sepasang bola mata. Namun, tidak sedikit yang iri dan terang-terangan mengibarkan permusuhan dengannya. Ara tidak mempunyai teman, tetapi tetap dapat merasakan tulusnya cinta Arnold dan Mario, sama-sama menyukai Ara. Namun, Ara telah memilih salah satunya yakni, Arnold. Kepada sang 
kekasih, ia sering bertanya seperti apa burung-burung terbang, seperti apa bintang-bintang bercahaya.

Di dalam penelitian ini, penulis mengambil tuturan yang terjadi pada dialog novel Sepasang Bola Matakarena di dalamnya terdapat banyak jenis tindak tutur ilokusi dan bentuk tindak tutur ilokusi yang menarik untuk diteliti lebih dalam. Dengan adanya beragam tuturan ilokusi yang ada pada novel Sepasang Bola Mata ini memudahkan penulis untuk mengidentifikasi tindak tutur terkait.

Berikut ini contoh tindak tutur ilokusi dalam dialog novel Sepasang Bola Mata.

Pertama: Dokter diam sesaat, lalu mulai memberitahukan analisisnya kepada Fatma perihal penglihatan anak Fatma. "Saya Khawatir anak ibu mengalami gangguan penglihatan, sehingga saya sarankan agar ia diperiksa lebih lanjut di dokter spesialis mata. Mudah-mudahan, penanganan dini ini bisa membuatnya kembali mendapatkan penglihatan!"

Berdasarkan data (1) dapat dijelaskan bahwa ucapan yang disampaikan penutur (Dokter Ibrahim) kepada mitra tutur (Fatma) bermaksud untuk menyarankan. Informasi yang dimaksud penutur (Dokter Ibrahim) dalam tuturannya yakni penutur (Dokter Ibrahim) menyarankan bahwa agar ia di periksa lebih lanjut di dokter spesialis mata. Penutur (Dokter Ibrahim) juga menginformasikan bahwa anak ibu Fatma mengalami gangguan penglihatan. Penanda lingual pada tuturan di atas yakni 'agar ia'. Tuturan di atas termasuk ke dalam jenis tindak tutur ilokusi karena memiliki maksud serta tujuan tertentu. Tuturan di atas menunjukkan tindak tutur ilokusi jenis representatif penutur hanya memberikan suatu kebenaran tanpa adanya suruhan atau mitra tutur melakukan suatu pekerjaan atau perbuatan. 


\section{Metode Penelitian}

Penelitian ini dilakukan untuk menganalisis bentuk dan fungsi tindak tutur ilokusi dalam novel Sepasang Bola Mata karta Mayshiza Widya. Sumber data penelitian ini adalah dialog dalam novel Sepasang Bola Mata karya Mayshiza Widya. Novel tersebut menceritakan tentang seorang gadis yang tidak mempunyai sepasang bola mata yang bernama Ara. Akan tetapi ayah dan ibu Ara akan selalu membuat hidup Ara bahagia. Sesuai dengan subjek penelitian ini yaitu novel, menggunakan metode deskriptif kualitatif karena data yang dihasilkan berupa kata-kata yang tertulis.

\section{Pembahasan}

\section{Jenis Tindak Tutur Ilokusi dalam Novel Sepasang Bola Mata}

Pada bab ini penulis akan membahas hasil penelitian terkait dengan judul "Tindak Tutur Ilokusi” dalam Novel Sepasang Bola Mata karya Mayshiza Widya yang berfokus pada tindak tutur ilokusi.

\section{(1) Jenis Tindak Tutur Ilokusi Representatif}

Penulis menemukan tindak tutur ilokusi jenis representatif ini pada data 01 berikut:

"Karir yang kau bangun selama ini akan sia-sia kalau kau memilih berhenti bekerja" lanjut Vivian. Ia berharap Fatma tak lagi keras kepala hingga menghancurkan segala mimpi dan ambisisnya menjadi wanita karier yang mapan dan memiliki masa depan menjanjikan.

"Kau tak akan mengerti. Apalagi kau belum pernah berada dalam fase ini. Menikah, menjadi istri, lalu menjadi ibu!" balas Fatma yang berdiri dan bergegas keluar meninggalkan kantor (SBM Hal 11).

Berdasarkan data 01 dapat dijelaskan bahwa ucapan yang disampaikan penutur (Fatma) kepada mita tutur (Vivian) bermaksud untuk menyatakan 
sesuatu. Tuturan yang dimaksud penutur (Fatma) dalam tuturannya adalah menikah, menjadi istri, lalu menjadi ibu tidak semudah yang dianggap mitra tutur (Vivian). Penanda lingual pada data tersebut yakni kata "Kau tak akan mengerti”. Penutur (Fatma) menyatakan kepada mitra tutur (Vivian) tanpa ada tendensi mempengaruhi tindak tutur agar tidak melakukan suatu tindakan tanpa mengetahui tentang penutur. Data (01) menunjukkan tindak tutur ilokusi representatif menyatakan sesuatu karena penutur (Fatma) tidak menuntut mitra tutur (Vivian) melakukan suatu hal atau pekerjaan. Maksud serta tujuan pertuturan adalah penutur (Fatma) menyatakan sesuatu menikah, menjadi istri, lalu menjadi ibu.

Selain itu, penulis juga menemukan tindak tutur ilokusi jenis representatif pada data 02 berikut ini.

"Sekarang ini mencari kerja itu sulit, Neng, apalagi bagi mereka yang tak punya pengalaman, koneksi, dan uang pelicin. Sarjana aja banyak yang nganggur, apalagi yang cuma lulusan rendahan!" Komentar sopir itu seperti ekonom saja(SMB Hal 13).

Berdasarkan data 02 dapat dijelaskan bahwa ucapan yang disampaikan penutur (Sopir) kepada mitra tutur (Fatma) bermaksud untuk membual/meremehkan. Tuturan yang dimaksud (Sopir) dalam tuturannya adalah "Sarjana aja banyak yang nganggur apalagi mereka yang Cuma lulusan rendahan!”. Penanda lingual adalah "Lulusan rendahan”. Penutur (Sopir) menyatakan sarjana aja banyak yang nganggur jadi seolah-olah penutur meremehkan sekaligus membual mitra tutur (Fatma). Data (02) menunjukkan tindak tutur ilokusi representatif membual sekaligus meremehkan karena penutur (Sopir) menuturkan kata-katanya tanpa memikirkan sakit hati (Fatma) penutur (Sopir) melakukan suata tindakan tanpa memikirka mitra tutur (Fatma).

Selain itu, penulis juga menemukan tindak tutur ilokusi jenis representatif pada data 03 berikut ini.

Fatma buru-buru turun. Ia agak kesal juga dengan tingkah pola yang ditunjukkan sopir tersebut. "Niat baik sih nggak apa-apa, tapi bikin malu," keluhnya sepanjang jalan(SBM Hal 14). 
Berdasarkan data 03 dapat dijelaskan bahwa ucapan yang disampaikan penutur (Fatma) kepada mitra tutur (Sopir) bermaksud mengeluh. Tuturan yang dimaksud (Fatma) dalam tuturannya adalah "Niat baik sih nggak apaapa, tapi bikin malu". Penanda lingual adalah "Bikin malu". Penutur (Fatma) mengeluh disepanjang jalan atas kelakuan mitra tutur (Sopir) sangat memalukan bagi penur (Fatma) karena banyak sekali penumpang Metromini. Data (03) menunjukkan tindak tutur ilokusi representatif mengeluh karena penutur (Fatma) mengeluh di sepanjang jalan atas tingkah laku sopir Metromini.

\section{(2) Jenis Tindak Tutur Ilokusi Ekspresif}

Penulis menemukan jenis tindak tutur ekspresif seperti pada data 01 berikut:

"Ara, Mas...., dia....," tangis Fatma kembali meledak, napasnya tersengal-sengal, dan kata-kata tak mampu tumpah ingin meski hatinya bicara banyak (SBM Hal 21).

Berdasarkan data 01 di atas dapat dijelaskan bahwa ucapan yang disampaikan penutur (Fatma) kepada mitra tutur (Tomy) yaitu tentang kondisi anaknya yang bernama Ara mengalami kebutaan. Penutur (Fatma) terlihat jelas bahwa yang di tuturkannya kepada mitra tutur yaitu kesedihan. Sedih karena anaknya mengalami kebutaan yang tidak di sangka-sangka penutur dan mitra tutur. Penanda lingual yaitu "Ara Mas dia..." karena dalam tuturannya Fatma sambil menangis tersengal-sengal.

Penulis menemukan tindak tutur yang berjenis ekspresif seperti pada data 02 berikut:

"Perasaan kecewa tentu saja tampak dari raut wajah Fatma, terlebih ucapan itu berasal dari mulut suaminya sendiri. Suatu hal yang membuatnya tak habis pikir. Kenapa orang-orang memandang Ara sebelah mata, padahal ia tumbuh sehat dan cerdas. Bahkan pertumbuhan dan perkembangannya lebih pesat dibandingkan anak-anak lain seusianya (SBM Hal 27). 
Bersadarkan data 02 di atas dapat dijelaskan bahwa ucapan yang disampaikan penutur (Fatma) kepada mitra tutur (Tomy) memiliki maksud dan tujuan tertentu. Karena penutur (Fatma) menyalahkan kenapaa orangorang memandang Ara sebelah mata, padahal ia tumbuh sehat dan cerdas. Disini penutur (Fatma) menyalahkan karena orang-orang melihat sebeleh mata saja tapi di balik semua itu Ara anak yang cerdas. Penanda lingual yaitu "kenapa orang-orang memandang Ara sebelah mata".

\section{(3) Jenis Tindak Tutur Ilokusi Direktif}

Penulis menemukan jenis tindak tutur ekspresif seperti pada data 01 berikut:

"Mas, anak kita mana? Dia baik-baik saja, bukan?" tanyanya mengharap kepastian. Suaminya tersenyum dan mengangguk kecil. Tapi, hal iti justru membuat Fatma kian panik dan takut telah terjadi sesuatu pada bayi yang ia lahirkan (SBM Hal 7).

Berdasarkan data (1)dapat dijelaskan bahwa ucapan yang disampaikan penutur (Fatma) kepada mitra tutur (Tomy). bermaksud bertanya apakah anaknya baik-baik saja yang bertujuan agar mitra tutur (Tomy) menjawab pertanyaan (Fatma) dapat digolongkan jenis tindak tutur direktif bertanya karena, bertujuan pada mitra tutur (Tomy) supaya menjawab pertanyaan sesuai yang dikehendaki penutur (Fatma). Selanjutnya, tuturan penutur (Fatma) yang menggunakan kata tanya berarti bermaksud untuk memaksa mitra tutur (Tomy) menjawab pertanyaannya. Penanda lingual di atas pada kata "Dia baik-baik saja bukan?". Tuturan di atas menunjukkan tindak tutur ilokusi jenis direktif.Penutur meminta mitra tutur menjawab suatu hal seperti yang di ujarkan oleh penutur.Berdasarkan percakapan yang berlangsung dapat diketahui bahwa reaksi yang ditimbulkan oleh mitra tutur senyum serta menyimak pertanyaan.Penutur berkeinginan agar mitra tutur mau menjawab pertanyaan mengharapkan kepastian.Berdasarkan mitra tutur dapat diketahui bahwa tindak tutur tersebut adalah tindak tutur yang berupa pertanyaan. 
Selanjutnya, penulis juga menemukan jenis tindak tutur direktif seperti pada data 02 berikut:

“Anak saya sehat kan, Dok?" tanya Fatma, hanya untuk memastikan bahwa tak ada yang ditutup-tutupi darinya. Dokter pun mengangguk dengan menatap.Dan setengah detik berikutnya, tangisan bayi memecah sunyi dan juga melegakan hati ibu tersebut. Fatma tersenyum sumringah saat suster yang menggendong bayi mungil itu datang dan menghampirinya yang masih tergeletak lemah,tak berdaya (SBM Hal 8).

Berdasarkan data (2)dapat dijelaskan bahwa ucapan yang disampaikan penutur (Fatma) kepada mitra tutur (Dokter).bermaksud bertanya apakah anaknya sehat yang bertujuan agar mitra tutur (Dokter) menjawab pertanyaan (Fatma) dapat digolongkan jenis tindak tutur direktif bertanya.karena, bertujuan pada mitra tutur (Dokter) supaya menjawab pertanyaan sesuai yang dipertanyakan penutur (Fatma). Selanjutnya, tuturan penutur (Fatma) yang menggunakan kata tanya berarti bermaksud untuk memaksa mitra tutur (Dokter) menjawab pertanyaannya. Penanda lingual di atas pada kata "Sehat kan Dok?".

\section{(4) Jenis Tindak Tutur Ilokusi Komisif}

Penulis menemukan tindak tutur yang berjenis komisif seperi pada data 01 berikut:

"Dan, apakah kau bisa membayangkan jika suatu hal itu sampai benar-benar terjadi? Dia akan marah pada dirinya sendiri seumur hidup, jadi kumohon lupakan impian bodoh itu. Dan aku berjanji akan mencari solusi lain untuk Ara. Dia anakku juga dan aku pun merasakan bagaimana kepedihanmu!" Tomy mengelus rambut istrinya yang panjang terurai (SBM Hal 24).

Berdasarkan data 01 dapat dijelaskan bahwa ucapan yang disampaikan penutur (Tomy) kepada mitra tutur (Fatma).bermaksudberjanji agar ia mencari solusi lain untuk Ara. yang bertujuan agar mitra tutur (Fatma) tidak melakukan suatu tindakan yang akan menyesal di kemudian hari.Penutur (Tomy) dapat digolongkan jenis tindak tutur 
komisifBerjanji.Karena, bertujuan pada mitra tutur (Fatma) supaya mendengarkan apa yang sudah di janjikan suaminya Tomy. Penanda lingual di atas pada kata "Aku Berjanji".

Tuturan di atas termasuk kedalam jenis tindak tutur ilokusi karena memiliki maksud dan tujuan tertentu.Penanda lingual di tandai pada kata“Aku Berjanji”. Tuturan di atas menunjukkan tindak tutur ilokusi jenis komisif. Penutur meminta mitra tutur mendengarkan janji seperti yang di ujarkan oleh penutur (Tomy).

Selanjutnya, penulis juga menemukanjenis tindak tutur komisifseperti pada data02 berikut:

"Nanti saja kalau kamu sudah besar. Ibu berjanji kamu akan sekolah di tempat anak-anak lain bersekolah. Disana kamu akan mendapatkan teman."

\section{"Ibu janji?"}

"Ya, Ibu berjanji, sayang," jawab Fatma lalu mencium kening anaknya dengan penuh cinta (SBM Hal 32).

Berdasarkan data 02 dapat dijelaskan bahwa ucapan yang disampaikan penutur (Fatma) kepada mitra tutur (Ara) bermaksud berjanji agar ia akan sekolah di tempat anak-anak lain bersekolah. yang bertujuan agar mitra tutur (Ara) dapat bergabung sama temen-temannya yang normal dan belajar bersama teman, tidak seperti yang di lakukan Penutur (Fatma) Homeschooling. Tuturan di atas termasuk kedalam jenis tindak tutur ilokusi karena memiliki maksud dan tujuan tertentu. Penanda ilokusi di tandai pada kata“'Ibu Berjanji". Tuturan di atas menunjukkan tindak tutur ilokusi jenis komisif Penutur meminta mitra tutur mendengarkan janji seperti yang di ujarkan oleh penutur (Fatma). 


\section{Bentuk-bentuk Tindak Tutur Ilokusi dalam Novel Sepasang Bola Mata \\ (1)Bentuk Tindak Tutur Langsung}

- Adapun bentuk tindak tutur langsung dapat di lihat pada data 01 seperti di bawah ini:

"Dipecat atau di-PHK ya, Neng?" tanya sang sopir ingin tahu (SBM Hal 13).

Konteks tuturan data 01 adalah sebagai berikut:

Aktivitas ini berlangsung ketika mitra tutur sedang berada di angkot penutur. Penutur langsung bertanya kepada mitra tutur dipecat atau di Phk karena ingin tahu tentang sebenarnya. Penutur lebih tua dari pada mitra tutur dan penur ikut prihatin kepada mitra tutur sehingga ongkos nya tidak usah dibayar sama mitra tutur.

Selanjutnya ditemukan konteks tuturan 02 sebagai berikut:

"Kamu sudah pulang, Fa?" tanya ibi Nuning, mertuanya (SBM Hal 14).

Konteks tuturan yaitu aktivitas ini berlangsung ketika penutur bertanya kepada mitra tutur Fatma. Usia tuturan ini penutur lebih tua dari pada mitra tutur, tuturan ini di tuturkan ketika berada disamping penutur dan terlihat jelas antara penutur dan mitra tutur akrab.

Selanjutnya ditemukan konteks tuturan 03 sebagai berikut:

"Bu katakan padaku apakah dunia itu indah?" tanya Ara yang kini mulai berjalan dan duduk di sebuah pelana kuda buatan (SBM Hal 33).

Konteks tuturan ini ketika sedang berlangsung penutur Ara dan mitra tutur Fatma. Penutur Ara bertanya kepada mitra tutur Fatma agar segera mitra tutur menjawab pertanyaannya tentang dunia itu indah. Kemudian, usia penutur lebih muda dari pada mitra tutur dan kejadian ini terlihat akrab antara penutur dan mitra tutur. 


\section{(2) Tindak Tutur Tidak Langsung}

Adapun bentuk tindak tutur tidak langsung dapat dilihat pada data 01 seperti di bawah ini:

“Halo, Mas, hari ini bisa pulang lebih cepat?" tanya Fatma dengan gusar.

“Ada apa?" tanya sang suami penuh wibawa.

"Ara sakit..., jawabnya pelan, sedih, dan hampir menangis (SBM Hal $85)$.

Konteks tuturan di atas secara tidak langsung penutur Fatma memberitahu suaminya lewat telepon agar mitra tutur pulang lebih cepat karena anak mereka Ara sedang sakit. Penutur lebih muda usianya dari pada mitra tutur.

Selanjutnya ditemukan bentuk konteks tindak tidak langsung pada data 02 sebagai berikut:

"Halo," sapanya

"Hai, Ara, apa kabar?" sapa sebuah suara

"Mario?" tanya Ara terkejut. Mendengar Ara merasa surprise...

Konteks tuturan di atas secara tidak langsung. Tindak tutur dan mitra tutur menyapa lewat teleponnya masing-masing dan terlihat jelas bahwa ini masuk ke dalam tindak tutur tidak langsung dan usia antara penutur dan mitra tutur tidak jauh beda.

Selanjutnya ditemukan bentuk konteks tindak tidak langsung pada data 03 sebagai berikut:

"Ya, ada apa Mario?" tanyanya tanpa sadar

“Kok kamu tahu kalau aku yang telpon?" balas Mario

Konteks tuturan di atas masuk ke dalam bentuk tindak tutur tidak langsung karena penutur dan mitra tutur berbicara lewat telepon. Penutur Ara langsung bertanya kepada mitra tutur Mario dan mitra tutur langsung meloncat kaget dan kejadian ini tidak terlihat oleh mitra tutur. 


\section{Simpulan}

Berdasarkan hasil analisis data dan pembahasan yang telah diuraikan dalam tindak tutur tokoh-tokoh pada novel Sepasang Bola Mata Karya Mayshiza Widya maka dapat disimpulkan sebagai berikut. Jenis tindak tutur ilokusi pada novel Sepasang Bola Mata menggunakan jenis tindak tutur asertif, ekspresif, direktif, komisif, dan deklaratif. Dari kelima tindak tutur ini penggunaan tindak tutur ekspresif paling banyak ditemukan karena dalam novel Sepasang Bola Mata mengandung kesedihan. Jenis tindak tutur asertif ditemukan 12 data, tindak tutur ekspresif ditemukan 13 data, tindak tutur direktif ditemukan 6 data, tindak tutur komisif ditemukan 5 data, dan tindak tutur deklaratif ditemukan 4 data. Bentuk tindak tutur ilokusi ditemukan hanya dua, yaitu: tindak tutur langsung ditemukan 10 data, dan bentuk tindak tutur tidak langsung ditemukan 8 data. Tindak tutur langsung yang banyak ditemukan karena dalam novel Sepasang Bola Mata karya Mayshiza Widya tuturan antartokoh yang sering muncul adalah tuturan secara langsung dari pada tuturan secara tidak langsung.

\section{Daftar Pustaka}

Austin, J. L 1962. How To Do Thing Word. New York: Oxford University Press.

Chaer, Abdul. 2007. Linguistik Umum, Jakarta: Rineka Cipta. 2010. Kesantunan Berbahasa Jakarta: Rineka Cipta.

Lubis, Hamid Hasan. 1991. Analisis Pragmatik. Bandung: Angkasa.

Mashun. 2005. Metode Penelitian Bahasa. Jakarta: PT. Raja Grafindo Persada.

Moleong, Lexy. 2015. Metodologi Penelitian Kualitatif. Bandung: PT Remaja Rosdakarya.

Muntolib. 2013. Tindak tutur Novel Para Abdi Sami Cecaturan Karya Mas Ngabehi Wasesa Pangawit: Universitas Muhamadiah 
Rahardi. Kunjana. 2009 Sosiopragmatik. Jakarta: Erlangga.

Rohmadi, Muhammad. 2010. Pragmatik Teori dan Analisis. Surakarta: Yuma Pustaka.

Suci Azzahra, SN. Tahun 2014. Penelitian Tindak Tutur Ilokusi dan Perlokusi dalam Iklan Sampo.

Stanton, Robert. 2012. Teori Fiksi Robert Stanton. Yogyakarya: Pustaka Pelajar Offset.

Sinaga, dkk. 2013. Tindak Tutur Dalam DialogIndonesia Lawyers Club oleh mengatur.

Tarigan, Henry Guntur. 2015. Pengajaran Pragmatik, Bandung: CV Angkasa.

1985. Pengajaran Pragmatik. Bandung Angkasa. 1986. Pengajaran Pragmatik. Bandung: Angkasa.

Bandung: Penerbit Angkasa. 2015. Pengajaran Ejaan Bahasa Indonesia,

Yule.2006 Pragmatik. Yogyakarta: Pustaka Pelajar.

Wijana. 1996. Dasar-dasar Pragmatik. Yogyakarta:

Wijana, J. Dewa Putu. 2004. Dasar-dasar Pragmatik. Yogyakarta: pen.Andi. 